\title{
Prevention of Malpractice in the Field of Health, as the Other Type of Prevention
}

\author{
Seyed Mansour Razavi, Farahnaz Khajehnasiri², Soheila Dabiran ${ }^{2}$ \\ ${ }^{1}$ Department of Community Medicine, Research Center for Rational Use of Drugs, Tehran University of Medical Sciences, \\ Tehran, Iran \\ ${ }^{2}$ Department of Community Medicine, Faculty of Medicine, Tehran University of Medical Sciences, Tehran, Iran \\ Email:khajenasiri@sina.tums.ac.ir, dabirans@sina.tums.ac.ir
}

How to cite this paper: Razavi, S.M., Khajehnasiri, F. and Dabiran, S. (2017) Prevention of Malpractice in the Field of Health, as the Other Type of Prevention. Open Journal of Preventive Medicine, 7, 183-194. https://doi.org/10.4236/ojpm.2017.79014

Received: July 9, 2017

Accepted: September 25, 2017

Published: September 28, 2017

Copyright (c) 2017 by authors and Scientific Research Publishing Inc. This work is licensed under the Creative Commons Attribution International License (CC BY 4.0).

http://creativecommons.org/licenses/by/4.0/

(c) (i) Open Access

\begin{abstract}
Background: So far, five types of prevention including: primordial, primary, secondary, tertiary and quaternary prevention levels have been defined in literatures. Aim: In this study, we have proposed "prevention of malpractice" as the other level of prevention. Methods: Qualitative comparison of the data, obtained from the review of conducted studies by using of scientific literatures, registered in PubMed, Google Scholar and Scopus sites. Results: Bringing dozens of examples of "malpractice" in the five areas of prevention. Conclusion: We concluded that, "malpractice" may be occurred at all levels of prevention and preventing it can be considered as the other level of prevention.
\end{abstract}

\section{Keywords}

Malpractice, Prevention Levels, Diseases, Disorders, Responsible

\section{Introduction}

Based on the Oxford Dictionary, Malpractice is "improper, illegal, or negligent professional behavior. The wrong doing, dereliction of duty, professional misconduct, breach of ethics, unprofessional behavior, unprofessionalism, unethical behavior, negligence, carelessness and incompetence" [1].

By this definition, malpractice will be considered at all levels of prevention. In Cambridge English Dictionary, malpractice defined as: "failure to act correctly or legally when doing your job, often causing injury or loss. They are accused of medical/financial/electoral malpractice" [2].

So far, five types of prevention have been defined. Primordial p. [reducing risk factors in community], Primary p. [reducing of diseases prevalence], Secondary 
p. [Early diagnosis, treatment and screening], Tertiary p. [reducing disabilities], and quaternary p. [reduce unnecessary medical interventions] [3] [4].

We believe that, "malpractice" may be occurred at all levels of prevention and this problem is a preventable subject at any level.

In our opinion, malpractice in the health field can occur in all levels of prevention by physicians, nursing, paramedical personnel, community health officials, policymakers, legislators and the patients or clients themselves, as well as, their family members.

In this study, we are going to discuss the "malpractice" in the framework of five levels of prevention, with common examples, and present some activities to prevent it.

\section{Methods}

This is a qualitative study in which, we have categorized information and data, obtained from the review of conducted studies by using of scientific literatures, registered in PubMed, Google Scholar and Scopus sites.

\section{Results}

We have tried to analyze "different types of malpractices" at each of the five known levels of prevention in this study. Some following examples can clarify the above explanation. In these examples, we have identified the health problems, malpractices and the main responsible for prevention of them among individuals or community.

\subsection{Primordial Prevention}

To prevent "malpractice" at the level of primordial, some examples are given in the Table 1. At this level of prevention, we address to socio-cultural and environmental factors.

\subsection{Primary Prevention}

To prevent "malpractice" at the level of primary prevention, some examples are given in the Table 2. At this level of prevention, we will pay more attention to individual factors.

\subsection{Secondary Prevention}

Include: Unreasonable request for medical diagnostic tests, late and misdiagnosis, mistake in timely treatment, irrational administration of drugs or blood transfusion, surgical or procedural errors and performing screening tests incorrectly [20].

\subsubsection{Unreasonable Request for Medical Diagnostic Tests Examples}

- Unreasonable request to perform various Lab. Examinations and imaging tests such as imaging for pregnant women, etc. 
Table 1. Primordial prevention examples including: health problems, malpractices and main responsible.

\begin{tabular}{|c|c|c|c|}
\hline Community health problems & Malpractice examples & $\begin{array}{l}\text { Main responsible for } \\
\text { prevention }\end{array}$ & Ref. \\
\hline $\begin{array}{l}\text { Socio cultural and environmental problems }{ }^{*} \text { such as: } \\
\text { child abuse, spouse abuse, elderly abuse, violence, } \\
\text { poor rules and laws, cultural, social problems, } \\
\text { unemployment, rapid social changes, limited } \\
\text { educational opportunities, begging, addiction, } \\
\text { prostitution, internet crimes, road and street } \\
\text { accidents, unequal access to healthcare, etc. }\end{array}$ & $\begin{array}{l}\text { Socio cultural and environmental mal- } \\
\text { practices can be as following: } \\
\text { - Ineffective legislation } \\
\text { - } \quad \text { wrong socio economic policies } \\
\text { - } \text { Weak management } \\
\text { - Poor planning } \\
\text { - Inconsistency } \\
\text { - Inadequate supervision. }\end{array}$ & $\begin{array}{l}\text { Can be as follows: } \\
\text { - } \text { Legislators } \\
\text { - } \text { sociocultural authorities } \\
\text { - Health managers } \\
\text { - drug control officials } \\
\text { - } \quad \text { social sciences experts } \\
\text { - } \text { welfare organizationauthorities } \\
\text { - } \text { municipalities }\end{array}$ & {$[5]-[12]$} \\
\hline $\begin{array}{l}\text { Economical related problems such as: } \\
\text { - Poverty } \\
\text { - Low Income } \\
\text { - Expensiveness } \\
\text { - Inflation } \\
\text { - Unfair distribution of wealth } \\
\text { - Multiple Job Life } \\
\text { - Economic downturn etc. }\end{array}$ & $\begin{array}{l}\text { Malpractice examples in economy can be } \\
\text { as follows: } \\
\text { - Inappropriate economic policies } \\
\text { - Weakness in smuggling control } \\
\text { - Immoderate imports, etc. }\end{array}$ & $\begin{array}{l}\text { Can be as follows: } \\
\text { - Economists } \\
\text { - Economic authorities } \\
\text { - } \text { Customs authorities } \\
\text { Ministry of Labour and Social } \\
\text { Affairs, etc. }\end{array}$ & $\begin{array}{c}{[8][9][10]} \\
{[11][12]}\end{array}$ \\
\hline $\begin{array}{l}\text { Environmental health problems including: } \\
\text { - Air, water and noise pollution } \\
\text { - Dispersion of solid waste and sewage } \\
\text { - Non-sanitary physical environment } \\
\text { - Increased cancer rates, etc. }\end{array}$ & $\begin{array}{l}\text { Environmental associated malpractices } \\
\text { such as: } \\
\text { - Inappropriate environmental health } \\
\text { policies } \\
\text { - Inappropriate methods such as: } \\
\text { Illegal dumping and incineration of } \\
\text { wastes } \\
\text { - Uncoordinated responsibleorgans, } \\
\text { etc. }\end{array}$ & $\begin{array}{l}\text { Environmental health authorities } \\
\text { - } \quad \text { Environmental Protection } \\
\text { Agency [EPA] } \\
\text { - } \quad \text { Ministry of Health } \\
\text { - Municipalities, etc. }\end{array}$ & [13] [14] \\
\hline
\end{tabular}

* That is the same as Social Determinants of Health (SDH) [9] [10] [11] [12] [13] [15].

Table 2. Primary prevention examples for reducing the malpractices.

\begin{tabular}{lll}
\hline Malpractice examples at the individual level* & Main responsible for prevention \\
\hline${ }^{*}$ Unsafe transferof a person suffering from spinal cord injury from & - Ordinary people on the crash scene \\
the place of injury to a hospital & - Pre-hospital emergency staff \\
Neglect of the patients with major depression for suicide prevention, & - Patient's family members \\
especially in patients with an attempt in the preceding year. & - Hospital personnel \\
Tooth staining of infants due to iron drip just on the teeth & $-\quad$ Pediatrician \\
& - Baby parents \\
Neglect of the foot hygiene [nail care and proper footwear] & - Diabetic patients themselves \\
Forgetting care of long sleep apnea & - Family physicians \\
Self-medication & - & The patient him/herself or his/her wife \\
\hline
\end{tabular}

${ }^{\star}$ Hundreds of common examples can be brought to person's malpractices on their own health status.

\subsubsection{Late and Misdiagnosis Examples}

- Inaccurate or late diagnosis, e.g. late HIV diagnosis which remains a major contributor to the mortality and morbidity in AIDS [21].

- Misinterpretation of para clinical test results, e.g. misinterpretation of false positive tests which may lead to wrong diagnosis and followed by doing wrong interventions, unnecessary medications and even drugs abuse [22]. 
- Mistakes in differentiating health problems such as, differentiation between septic arthritis and gout [23].

- Attribution of somatic symptoms to mental disorders [e.g. hypochondriasis] incorrectly [24].

\subsubsection{Mistake in Timely Treatment Examples}

Interfere with factors like: Neglect-forgetting-and not being succeeded in control of diseases. Examples include:

- Neglect: This mistake can lead to bigger problems, such as: neglect the cholecystitis in diabetic patients which may lead to gallbladder perforation and early surgery is highly recommended in symptomatic gallstones and acute cholecystitis in these patients [25]. As well as, hyperbilirubinemia in neonates which can lead topermanent and irreversible brain damage due to bilirubin encephalopathy and Kern icterus [26], prehypertension which even in the low range, elevates the risk of cardiovascular disease [CVD] [27], child abuse which may threaten the child's life [5], etc.

- Forgetting: To forget the co-infections or super-infections treatment, to forget the sexual partner's treatment [if needed] in STIs, which may lead to survival of the disease, etc.

- Unsuccessful disease treatment: hypertension [stroke] [28], diabetes mellitus [gradual occurrence of blindness-kidney failure and diabetic foot-CVA etc.] [29], Failure of Helicobacter Pyloricontrol [increased risk of stomach cancer] [30] and failure of STIs control [infertility-chronic PID ectopic pregnanc-neonatal infections-Genital Cancer-impregnation-spontaneous abortion-Congenital anomalies etc.] [30].

\subsubsection{Irrational Administration of Drugs Examples}

- Mistake in dosage regulation and application methods of drugs which may lead to occurrence of complications, e.g. Overdosing of theophylline can cause arrhythmias and seizures [31].

- Widespread and irrational use of antibiotics by practitioners, veterinarians, breeders and farmers which can provide conditions for fungal growth or broadcasting of microbial resistance and improper ecological and environmental damages [32].

- Irrational use of corticosteroids which can lead to numerous complications like, flare up the latent tuberculosis-immunosuppression-adrenal suppression-cushingoid appearance and weight gain-hypertension-osteoporosispathologic fractures and osteonecrosis-myopathy - hyperglycemia and flare up of diabetes mellitus and latent dyslipidemia-cataracts and glaucoma-skin atrophy-hyperpigmentation-telangiectasis-psychiatric and cognitive disturbances and the other complications [33].

- Irrational use of hypnotic and confusing drugs, especially in the elderly patients which increases the risk of falling [34].

- Prescribing aspirin for children and teenagers $<18$ years of age in influenza 
outbreaks and chicken pox which facilitating the development of Ray's syndrome [acute encephalopathy] [35].

- Administration aspirin in asthmatic patients and chronic rhinosinusitis with nasal polyposis which may lead to exacerbation of respiratory disease [36].

- Administration of antibiotics in upper respiratory viral infections, asthma and bronchitis, and skin abscesses which often they are useless and cause microbial resistance.

- Uncontrolled administration of anticoagulants which may cause various bleeding in all parts of the body especially GI and intracranial hemorrhage [37].

- Prescription of contraceptives without confirmed indication can increase the risk of some complications like obesity, venous and arterial thrombosis such as DVT, myocardial infarction and ischemic stroke [38].

- Irrational prescription of diuretics which can lead to electrolyte disturbances like hyperkalemia orhypokalemic, hypochloremic, hyponatremia, volume depletion, ototoxicity, nephrocalcinosis, nephrolithiasis, hypomagnesemia, hyperuricemia, noncardiogenic pulmonary edema, pancreatitis, and myalgias [39].

- Administration of toxic drugs without accurate monitoring in patients with a prone background can lead to severe complications. Current drugs such as isoniazid, rifampicin and pyrazinamide, used in tuberculosis are potentially hepatotoxic and may lead to drug hepatitis [40]. Administration of hepatotoxic anti-tuberculosis drugs in a patient with hepatitis can lead to liver failure, since many diabetic patients have chronic kidney disease, nephrotoxic drugs should be prescribed with caution, or long-term use of ototoxic drugs such as streptomycin in elderly patients can cause hearing loss or deafness, because of streptomycin has a serious ototoxic effect [41].

- Over dosage of calcium and vitamin D can cause renal damage.

- Iron prescription in thalassemia may lead to hemosiderosis. Patients with major thalassemia need lifelong transfusions. The consequence of these repeated transfusions is iron accumulation in heart, liver and pancreas [42].

- Inappropriate Prescribing of hypoglycemic drugs may lead to hypoglycemia, Coma [the most common neurological symptom], epileptic seizures [not as common as previously assumed], loss of brain cells and death [43].

- Irrational use of high-dose of antihypertensive drugs, especially in elderly patients can lead to sudden drop in blood pressure and stroke.

- Use of inappropriate doses of anti-fatty drugs such as lovastatin and gemfibrozil can lead to liver biliary, muscle and kidney disturbances.

- Delay in timely administration of oseltamivir in the elderly patients with severe influenza can even lead to death among them.

- Simultaneous administration of MAOIs with opioids in addicts can cause delirium and death.

- Prescription of sexual stimulant drugs for impotence and many other examples in this field. 


\subsubsection{Examples of Mistakes That May Occur in Surgeries}

- Anesthesia and surgeries done by people who are not skilled.

- Unnecessary surgeries, such as some prostatectomies which can lead to impotence, splenectomies which may lead to invasive pneumococcal infections [44], improper limbs amputations or unnecessary mastectomies which cause permanent disabilities, etc.

- Surgery of healthy side, e.g., a healthy eye instead of a defective eye, right inguinal hernia instead of the left one, etc.

- Surgical mistakes of patients with name similarity which impose the physical and financial impose to the patient.

- Use of contaminated equipment which may lead to nosocomial infections.

- Delay in the treatment of malignant tumors which causes progression of tumor and metastasis of the cancers.

- Resection of tumors with insufficient affected margin which causes relapse.

- Surgery of patients with severe metastasis which impose pain and cost.

- Additional abdominal surgery with diagnosis of acute abdomen due to abdominal muscle spasms in tetanus.

- Postponing the surgery and entering additional stress to the patients.

- Slicing of tuberculosis abscesses that lead to chronic fistula and scarring.

- Leaving the equipment in the patient's body.

- Over dosage of anesthetics drugs which can lead to serious complications.

- Mistaken use of toxic gases instead of oxygen in the patient's anesthetic process which can lead to death.

\subsubsection{Examples of Mistakes That May Occur in the Other Procedures}

- Impose discomfort, pain and cost to the patients in the endoscopic technics.

- Injection of expired date BCG, more than recommended doses orselecting an inappropriate place for injects which may lead to tuberculosis lymphadenitis in baby.

- Sudden evacuation of ascites fluid without blood replacement which may causes shock.

- Dressing the wound of the bite location from a suspected rabid animal which my facilitated the rabies.

- Damage of adjacent teeth when working on decayed teeth.

- Carrying out the exercise test without exact supervision which may lead to heart attack or even death.

- Uncontrolled phlebotomy [patient hemoglobin should not be normalized to phlebotomy.

- Repeated injection of corticosteroids into the joints which can lead to infections.

\subsection{Tertiary Prevention}

To prevent "malpractice" at the level of tertiary prevention, some examples are given in the Table 3. At this level of prevention, we will pay more attention to 
Table 3. Examples for, rehabilitation measures to compensate the complications due to malpractice.

\begin{tabular}{|c|c|c|c|c|}
\hline Background & Malpractice & complication & $\begin{array}{c}\text { Compensatory } \\
\text { rehabilitation measures }\end{array}$ & Ref. \\
\hline \multirow{2}{*}{ Old age } & Irrational administration of hypnotic drugs & $\begin{array}{l}\text { Falling (fractures } \\
\text { e.g. Hip fracture) }\end{array}$ & Use of prosthesis, walker, cane, etc. & [25] \\
\hline & $\begin{array}{l}\text { Administration of streptomycin without hearing } \\
\text { monitoring forearly detection of ototoxicity }\end{array}$ & Hearing loss, Deafness & Use of hearing aids & {$[45]$} \\
\hline \multirow{2}{*}{ Diabetes mellitus } & Amputation without indication in diabetic foot & Disability & Use of artificial limb & [46] [47] \\
\hline & Neglect of Periodic Examination of the eyes & Diabetic retinopathy & Use of the laser & [48] \\
\hline \multirow{2}{*}{$\begin{array}{l}\text { Tuberculosis skin } \\
\text { abscess/Joint } \\
\text { tuberculosis }\end{array}$} & Excision the abscess without medication & $\begin{array}{l}\text { Persistent fistula, chronic } \\
\text { scar }\end{array}$ & plastic surgery & [49] \\
\hline & $\begin{array}{l}\text { Late diagnosis (The infection requires immediate } \\
\text { surgical debridement or drainage). }\end{array}$ & Destruction of the joint & Hip replacement) & {$[50]$} \\
\hline $\begin{array}{l}\text { Sexual transmitted } \\
\text { infections [STIs] }\end{array}$ & Failure in correct treatment & $\begin{array}{l}\text { Adhesion of pelvic tissues } \\
\text { [infertility-PID—etc.] }\end{array}$ & $\begin{array}{c}\text { Pelvic physiotherapy } \\
\text { IUI } \\
\text { IVF }\end{array}$ & [51] [52] \\
\hline
\end{tabular}

individual factors. Please refer to Table 3.

\subsection{Quaternary Prevention}

"Quaternary prevention is a group of measures taken to prevent, decrease and/or alleviate the harm caused by health activities" [44]. In our view, carrying out of any unnecessary medical activity without none necessary scientific backing up is the same "malpractice". This concept requires a brief discussion that we have dealt with it in the discussion section.

\section{Discussion}

Primordial level of prevention, emphasis on prevention of emergence the social and environmental predisposing conditions which can lead to diseases [4]. Usually, the responsible for organizing of social and environmental health problems are social officials such as: Legislators-policymakers-sociocultural authorities-managers-social workers-social science specialists-welfare authorities-Municipalities etc. All of these officials can make mistakes in their works and activities.

In primary, secondary and tertiary levels, usually we emphasize on individual practices. In these cases, the activities are focus on self-care or doctor interventions.

For definition of quaternary level of prevention, there are used some terms such as: excesses of medicine, over-medicalization, overuse of drugs, over diagnosis, unnecessary treatment and unnecessary medical interventions. What is certain is that, these measures impose considerable discomforts, complications or costs. In quaternary prevention, "attitude" has the first role in practices.

The main question is whether these measures, which are often carried out by the physicians, are not really a kind of malpractice? Are these as "good" practices? In our opinion, all these expressions represent "bad" or "mal" acts in the sacred profession of medicine, and physicians must endeavor to offer the heal- 
thiest services to the people. If so they use a guideline in their practice, the guide line needs to be revised and the main culprits in this phenomenon are compilers of the guide lines.

Practical suggestions for reducing malpractices:

- Taking an accurate medical history and examining all the organs of the body.

- Paying more attention to the warning signs.

- Use of the valid guide lines.

- Pay attention to indications in carrying out of any medical measures and procedures.

- Rational administration of drugs, especially antibiotics [prescribing according to age, sex, history, dosage, duration of use, route of administration, drug interactions, complications, etc.] By doctors and pharmacists.

- To avoid from "unreasonable request for medical diagnostic tests" for laboratory and imaging tests.

- Monitor the function of target organs such as the liver, kidneys, the hearing system, etc. when using drugs, especially antibiotics.

- Carrying out the timely surgery or any other diagnostic and curable measures.

- Mark on the side which is candidate for surgery.

- Reduce the duration of surgery as much as possible.

- Reduce the length of hospital stay as much as possible.

- Proper refinement, purification and correct use of the blood and blood products.

- Precise monitoring of water and electrolytes balance in the body.

- Psychological, psychiatrics, nutritional and the other specialties counseling.

- Timely and accurate referral of the patients to specialized centers.

- Enhance professional skills training.

- Applying experienced people in all interventions.

- Use of standard equipment for diagnostic, remedial and rehabilitation destinations.

- Gradually taper of the corticosteroids. And many other preventive measures.

\section{Conclusion}

We concluded that, "malpractice" may be occurred at all levels of prevention and reducing of malpractices can be considered as the other level of prevention.

\section{Acknowledgements}

Hereby, we would sincerely like to appreciate Belgian general practitioner Marc Jamoulle for innovation.

Of the fourth level of prevention.

\section{Conflict of Interests}

There is no conflict of interest in the study. 


\section{References}

[1] Oxford University Press (1884) Oxford Dictionary. https://en.oxforddictionaries.com/definition/malpractice.

[2] Cambridge University Press (1995) Cambridge English Dictionary. http://dictionary.cambridge.org/dictionary/english/malpractice.

[3] Jamoulle, M. (2014) The Four Duties of Family Doctors. Quaternary Prevention: First, Do No Harm. Hong Kong Practitioner, 36, 46-49.

[4] Starfield, B., Hyde, J., Gérvas, J. and Heath, I. (2008) The Concept of Prevention: A Good Idea Gone Astray? Journal of Epidemiology \& Community Health, 62, 580-583. https://doi.org/10.1136/jech.2007.071027

[5] Aslan, F., Erkol, Z.Z., Timur, S. and Bulut, H. (2017) Chronic Abuse of the Three Brothers and Negligence up to the Level of Cachexia-Case Report. Medicine Science, 6, 389-613. https://doi.org/10.5455/medscience.2017.06.8651

[6] Mikton, C.R., Butchart, A., Dahlberg, L.L. and Krug, E.G. (2016) Global Status Report on Violence Prevention 2014. American Journal of Preventive Medicine, 50, 652-659. https://doi.org/10.1016/j.amepre.2015.10.007

[7] Kuo, M., Shamsian, A., Tzemis, D. and Buxton, J.A. (2014) A Drug Use Survey among Clients of Harm Reduction Sites across British Columbia, Canada, 2012. Harm Reduction Journal, 11, 13. https://doi.org/10.1186/1477-7517-11-13

[8] Bahadori, M., Sanaeinasab, H., Ghanei, M., Mehrabi Tavana, A., Ravangard, R. and Karamali, M. (2015) The Social Determinants of Health (SDH) in Iran: A Systematic Review Article. Iranian Journal of Public Health, 44, 728-741.

[9] Commission on Social Determinants of Health (2008) Closing the Gap in a Generation: Health Equity through Action on the Social Determinants of Health. Final Report of the Commission on Social Determinants of Health. World Health Organization, Geneva, Switzerland. http://whqlibdoc.who.int/publications/2008/9789241563703_eng.pdf

[10] Garrett, B.E., Dube, S.R., Babb, S. and McAfee, T. (2015) Addressing the Social Determinants of Health to Reduce Tobacco-Related Disparities. Nicotine \& Tobacco Research, 17, 892-897. https://doi.org/10.1093/ntr/ntu266

[11] Braveman, P. and Gottlieb, L. (2014) The Social Determinants of Health: It's Time to Consider the Causes of the Causes. Public Health Reports, 129, 19-31. https://doi.org/10.1177/00333549141291S206

[12] Bahadori, M., Sanaeinasab, H., Ghanei, M., Tavana, A.M., Ravangard, R. and Karamali, M. (2015) The Social Determinants of Health in Military Forces of Iran: A Qualitative Study. Journal of Environmental and Public Health, 2015, Article ID: 524341.

[13] Marconato, L., Leo, C., Girelli, R., Salvi, S., Abramo, F., Bettini, G., Comazzi, S., Nardi, P., Albanese, F. and Zini, E. (2009) Association between Waste Management and Cancer in Companion Animals. Journal of Veterinary Internal Medicine, 23, 564-569. https://doi.org/10.1111/j.1939-1676.2009.0278.x

[14] Javaheri, S., Barbe, F., Campos-Rodriguez, F., Dempsey, J.A., Khayat, R., Javaheri, S., et al. (2017) Sleep Apnea: Types, Mechanisms, and Clinical Cardiovascular Consequences. Journal of the American College of Cardiology, 69, 841-858.

[15] Ahoniemi, E., Savolainen, S., Malmivaara, A., Pohjolainen, T., Baer, G., Dahlberg, A., Hellström, P., Kankare, J., Ronkainen, A. and Ylinen, A. (2013) Update on Current Care Guidelines: Spinal Cord Injury. Duodecim, 129, 262-263.

[16] Nanayakkara, S., Misch, D., Chang, L. and Henry, D. (2013) Depression and Expo- 
sure to Suicide Predict Suicide Attempt. Depression and Anxiety, 30, 991-996. https://doi.org/10.1002/da.22143

[17] Bandon, D., Chabane-Lemboub, A. and Le Gall, M. (2011) Exogenous Tooth Discoloration in Children: Black Stains. Archives de pediatrie: Organeofficiel de la Societefrancaise de pediatrie, 18, 1348-1352.

[18] Nongmaithem, M., Bawa, A.P., Pithwa, A.K., Bhatia, S.K., Singh, G. and Gooptu, S. (2016) A Study of Risk Factors and Foot Care Behavior among Diabetics. Journal of Family Medicine and Primary Care, 5, 399. https://doi.org/10.4103/2249-4863.192340

[19] Damian, L., Lupuşoru, C.E. and Ghiciuc, C.M. (2014) Self-Medication with Antimicrobial Drugs among University Students in a Northeast Region of Romania. Revista Medico-Chirurgicala a Societatii de Medicisi Naturalisti din Iasi, 118, 160-164.

[20] Piercecchi-Marti, M.D., Tuchtan-Torrents, L., Lassale, B., Leonetti, G. and Bartoli, C. (2014) Responsibility for Prescribing and Monitoring an Act Transfusion and Safety Blood Transfusion. Transfusion Clinique ET Biologique: Journal de la Societefrancaise de transfusion sanguine, 21, 158-161.

[21] Dai, S.Y., Liu, J.J., Fan, Y.G., Shan, G.S., Zhang, H.B., Li, M.Q. and Ye, D.Q. (2015) Prevalence and Factors Associated with Late HIV Diagnosis. Journal of Medical Virology, 87, 970-977. https://doi.org/10.1002/jmv.24066

[22] Brahm, N.C., Yeager, L.L., Fox, M.D., Farmer, K.C. and Palmer, T.A. (2010) Clinical Consultation. Commonly Prescribed Medications and Potential False-Positive Urine Drug Screens. American Journal of Health-System Pharmacy, 67. https://doi.org/10.2146/ajhp090477

[23] Lee, K.H., Choi, S.T., Lee, S.K., Lee, J.H. and Yoon, B.Y. (2015) Application of a Novel Diagnostic Rule in the Differential Diagnosis between Acute Gouty Arthritis and Septic Arthritis. Journal of Korean Medical Science, 30, 700-704. https://doi.org/10.3346/jkms.2015.30.6.700

[24] Neng, J. and Weck, F. (2015) Attribution of Somatic Symptoms in Hypochondriasis. Clinical Psychology \& Psychotherapy, 22, 116-124. https://doi.org/10.1002/cpp.1871

[25] Landau, O., Deutsch, A.A., Kott, I., Rivlin, E. and Reiss, R. (1992) The Risk of Cholecystectomy for Acute Cholecystitis in Diabetic Patients. Hepato-Gastroenterology, 39, 437-438.

[26] Kaplan, M., Bromiker, R. and Hammerman, C. (2011) Severe Neonatal Hyperbilirubinemia and Kernicterus: Are These Still Problems in the Third Millennium? Neonatology, 100, 354-362. https://doi.org/10.1159/000330055

[27] Huang, Y., Wang, S., Cai, X., Mai, W., Hu, Y., Tang, H. and Xu, D. (2013) Prehypertension and Incidence of Cardiovascular Disease: A Meta-Analysis. BMC Medicine, 11, 177. https://doi.org/10.1186/1741-7015-11-177

[28] Pistoia, F., Sacco, S., Degan, D., Tiseo, C., Ornello, R. and Carolei, A. (2016) Hypertension and Stroke: Epidemiological Aspects and Clinical Evaluation. High Blood Pressure \& Cardiovascular Prevention, 23, 9-18. https://doi.org/10.1007/s40292-015-0115-2

[29] Althaus, F.A. (1991) An Ounce of Prevention STDs and Women's Health. Family Planning Perspectives, 23, 173-177. https://doi.org/10.2307/2135741

[30] Wang, F., Meng, W., Wang, B. and Qiao, L. (2014) Helicobacter Pylori-Induced Gastric Inflammation and Gastric Cancer. Cancer Letters, 345, 196-202.

[31] Paloucek, F.P. and Rodvold, K.A. (1988) Evaluation of Theophylline Overdoses and 
Toxicities. Annals of Emergency Medicine, 17, 135-144.

[32] Zdziarski, P., Simon, K.R. and Majda, J.A. (2003) Overuse of High Stability Antibiotics and Its Consequences in Public and Environmental Health. Acta Microbiologica Polonica, 52, 5-13.

[33] Liu, D., Ahmet, A., Ward, L., Krishnamoorthy, P., Mandelcorn, E.D., Leigh, R., Brown, J.P., Cohen, A. and Kim, H. (2013) A Practical Guide to the Monitoring and Management of the Complications of Systemic Corticosteroid Therapy. Allergy, Asthma \& Clinical Immunology, 9, 30. https://doi.org/10.1186/1710-1492-9-30

[34] Obayashi, K., Araki, T., Nakamura, K., Kurabayashi, M., Nojima, Y., Hara, K., Nakamura, T. and Yamamoto, K. (2013) Risk of Falling and Hypnotic Drugs: Retrospective Study of Inpatients. Drugs in R\&d, 13, 159-164. https://doi.org/10.1007/s40268-013-0019-3

[35] Pfaffenbach, G., Tourinho, F.S. and Bucaretchi, F. (2010) Self-Medication among Children and Adolescents. Current Drug Safety, 5, 324-328. https://doi.org/10.2174/157488610792246028

[36] Simon, R.A., Dazy, K.M. and Waldram, J.D. (2015) Aspirin-Exacerbated Respiratory Disease: Characteristics and Management Strategies. Expert Review of Clinical Immunology, 11, 805-817. https://doi.org/10.1586/1744666X.2015.1039940

[37] Levine, M. and Goldstein, J.N. (2014) Bleeding Complications of Targeted Oral Anticoagulants: What Is the Risk? ASH Education Program Book, 5, 504-509. https://doi.org/10.1182/asheducation-2014.1.504

[38] Lobert, M., Pigeyre, M., Gronier, H., Catteau-Jonard, S. and Robin, G. (2015) Contraception et obésité. Gynécologie Obstétrique \& Fertilité, 43, 740-747.

[39] Greenberg, A. (2000) Diuretic Complications. The American Journal of the Medical Sciences, 319, 10-24.

[40] Ngouleun, W., Nya, P.C., Pieme, A.C. and Telefo, P.B. (2016) Risk Assessment of Hepatotoxicity among Tuberculosis and Human Immunodeficiency Virus/AIDS-Coinfected Patients under Tuberculosis Treatment. International Journal of Mycobacteriology, 5, 482-488.

[41] Kinis, V., Ozbay, M., Bakir, S., Sengul, E., Yorgancilar, E., Keles, A., Alabalik, U. and Meric, F. (2013) The Effect of Corticosteroid against Streptomycin Ototoxicity. Journal of Craniofacial Surgery, 24, 1726-1730. https://doi.org/10.1097/SCS.0b013e3182a232a5

[42] Azita Azarkeivan, M.D., Hashemieh, M. and AfshanShirkavand, M.D. (2016) Correlation between Heart, Liver and Pancreas Hemosiderosis Measured by MRI T2 among Thalassemia Major Patients from Iran. Archives of Iranian Medicine, 19, 96.

[43] Halawa, I., Zelano, J. and Kumlien, E. (2015) Hypoglycemia and Risk of Seizures: A Retrospective Cross-Sectional Study. Seizure, 25, 147-149.

[44] Polák, P., Freibergerová, M., Husa, P., Slesinger, P., Svoboda, R., Stásek, J., Frola, L. and Macháček, C. (2012) Warning about Risk of Invasive Infections in Splenectomized Patients. Experiences from University Hospital Brno, Czech Republic, in 2011. Vnitrnilekarstvi, 58, 665-667.

[45] Adeyemo, A.A., Oluwatosin, O. and Omotade, O.O. (2016) Study of Streptomycin-Induced Ototoxicity: Protocol for a Longitudinal Study. Springerplus, 5, 758. https://doi.org/10.1186/s40064-016-2429-5

[46] Weledji, E.P. and Fokam, P. (2014) Treatment of the Diabetic Foot-To Amputate or Not? BMC Surgery, 14, 83. https://doi.org/10.1186/1471-2482-14-83

[47] Arifin, N., Abu Osman, N.A., Ali, S. and Wan Abas, W.A. (2014) The Effects of 
Prosthetic Foot Type and Visual Alteration on Postural Steadiness in Below-Knee Amputees. BioMedical Engineering OnLine, 13, 23. https://doi.org/10.1186/1475-925X-13-23

[48] Yun, S.H. and Adelman, R.A. (2015) Recent Developments in Laser Treatment of Diabetic Retinopathy. Middle East African Journal of Ophthalmology, 22, 157-163. https://doi.org/10.4103/0974-9233.150633

[49] Altaf Mir, M., Ahmad, I. and Yaseen, M. (2016) Primary Tuberculosis of Hand Soft Tissue. World Journal of Plastic Surgery, 5, 313-318.

[50] Fujioka, M., Yoshida, S., Kitamura, R. and Matsuoka, Y. (2008) Iliopsoas Muscle Abscess Secondary to Sacral Pressure Ulcer Treated with Computed Tomography-Guided Aspiration and Continuous Irrigation: A Case Report. Ostomy Wound Management, 54, 44-48.

[51] Trent, M., Bass, D., Ness, R.B. and Haggerty, C. (2011) Recurrent PID, Subsequent STI, and Reproductive Health Outcomes: Findings from the PID Evaluation and Clinical Health (PEACH) Study. Sexually Transmitted Diseases, 38, 879-881. https://doi.org/10.1097/OLQ.0b013e31821f918c

[52] Wurn, B.F., Wurn, L.J., King, C.R., Heuer, M.A., Roscow, A.S., Scharf, E.S. and Shuster, J.J. (2004) Treating Female Infertility and Improving IVF Pregnancy Rates with a Manual Physical Therapy Technique. Medscape General Medicine, 6, 5.

\section{Submit or recommend next manuscript to SCIRP and we will provide best service for you:}

Accepting pre-submission inquiries through Email, Facebook, LinkedIn, Twitter, etc. A wide selection of journals (inclusive of 9 subjects, more than 200 journals) Providing 24-hour high-quality service User-friendly online submission system Fair and swift peer-review system Efficient typesetting and proofreading procedure Display of the result of downloads and visits, as well as the number of cited articles Maximum dissemination of your research work

Submit your manuscript at: http://papersubmission.scirp.org/ Or contact ojpm@scirp.org 